\title{
The Good Food Purchasing Policy: A tool to intertwine worker justice with a sustainable food system
}

Joann Lo ${ }^{a *}$

Food Chain Workers Alliance

Alexa Delwiche ${ }^{b}$

Center for Good Food Purchasing

Submitted October 6, 2015 / Revised December 21, 2015, and January 29, 2016 /

Accepted January 29, 2016 / Published online March 18, 2016

Citation: Lo, J., \& Delwiche, A. (2016). The Good Food Purchasing Policy: A tool to intertwine

worker justice with a sustainable food system. Journal of Agriculture, Food Systems, and Community

Development, 6(2), 185-194. http://dx.doi.org/10.5304/jafscd.2016.062.016

Copyright (C) 2016 by New Leaf Associates, Inc.

\begin{abstract}
Public procurement is a strategy to transform the food system into one that is more sustainable and just. The Good Food Purchasing Policy (GFPP), developed by the Los Angeles Food Policy Council in 2012, leverages taxpayer funds to support local producers, environmentally sustainable production practices, good jobs, humane treatment of animals, and healthy food. Based on the experience of developing and winning the adoption of the policy in Los Angeles, GFPP has the potential to bring together the various sectors of the food movement around a shared vision and strategy for change. In this reflective essay, we provide an insiders' look
\end{abstract}

a* Corresponding author: Joann Lo, Food Chain Workers Alliance; 1730 West Olympic Boulevard \#300; Los Angeles, California 90015 USA; +1-213-380-4060; joann@,foodchainworkers.org

b Alexa Delwiche, Center for Good Food Purchasing; P.O. Box 7243; Berkeley, California 94707 USA; +1-805-570-3659; adelwiche@,cfgfp.org into the policy, its impact to date, and its potential in the future.

\section{Keywords}

procurement, movement-building, food workers, sustainability, good food, GFPP, Good Food Purchasing Policy

\footnotetext{
Disclosure and Authors Note

Joann Lo is co-director of the Food Chain Workers Alliance. She co-chaired the working group of the Los Angeles Food Policy Council (LAFPC), which developed the Good Food Purchasing Policy. She also provides technical advice and support for the implementation of the GFPP in Los Angeles, and serves on the board of directors of the Center for Good Food Purchasing. She is also chair of the Leadership Board of the LAFPC. Alexa Delwiche facilitated the research and writing of the Good Food Purchasing Policy and Standards through the multisector stakeholder working group of the LAFPC and is now executive director of the new Center for Good Food Purchasing. This reflective essay is based on the authors' experience and observations in developing and implementing the GFPP.
} 


\section{Introduction}

In recent years, the sustainable food movement has begun to pay attention to problems that food chain workers face, such as poverty wages, dangerous working conditions, wage theft, and food insecurity (Bittman, 2015; Myers \& Sbicca, 2015; Sbicca, 2014). It has not been clear how to address these problems in collaboration with the food movement in order to advance structural and political changes in the food system (Pollan, 2011). The Good Food Purchasing Policy, developed by the Los Angeles Food Policy Council, offers a model policy that brings together the various sectors of the sustainable food movement to work toward a common goal. In this article, we will discuss the development of the policy, its impact to date, and its potential for becoming a national model.

A number of authors have noted that the food movement is not unified. Some see multiple movements rather than one (Holt-Giménez \& Wang, 2011; Pollan, 2010). At times, those in the food movement "work at cross-purposes" (Pollan, 2010, para. 11).

The potential for a unified food movement exists, however, and there are indications that such a movement may have already begun (Pollan, 2010, para. 12). The HEAL (Health, Environment, Agriculture, and Labor) Food Alliance was created in 2014 as an attempt to bring together the multiple sectors of the food movement. The HEAL Food Alliance is a national coalition of food movement coalitions and organizations anchored by the Movement Strategy Center, Real Food Generation, the Union of Concerned Scientists, and the Food Chain Workers Alliance.

As the food movement experiences increasing convergence, many recognize that consumeroriented campaigns urging individuals to "buy local" or "buy sustainable" are insufficient to bring about systemic change in our food system. Over the last decade, procurement policies leveraging the large-scale buying power of food service institutions have become an increasingly popular tool in supporting local and sustainable food systems (Bartlett, 2011). In particular, policies focus on the role of government entities as major food buyers and their moral imperative to support a more equitable, sustainable, and healthy food system when buying food for schools, hospitals, and public administrations with taxpayer funds (de Schutter, 2014).

The impact of these procurement policies is still unclear and questionable. There is insufficient attention paid to implementation, and it can be difficult to track purchases and verify if shifts are occurring in purchasing practices (Bartlett, 2011). More fundamentally, critiques center around the limited ability of procurement policies to transcend a single-issue area. Procurement policies have historically reflected the underlying tensions within the food movement because of the policies' inherent trade-offs (Friedmann, 2007). Procurement policies typically emphasize local sourcing, nutrition, or, in some cases, environmental sustainability. The rights of workers are seldom, if ever, mentioned (Delwiche \& Lo, 2013). The closest that institutions have come to monitoring food chain working conditions has been symbolic, through the adoption of sweatfree procurement policies by government institutions in many U.S. cities, including Los Angeles. Through a sweatfree procurement policy, public institutions commit to buying apparel from vendors and subcontractors that comply with domestic and international labor laws. However, resources are rarely put into enforcement of these policies. While some of these policies apply de facto to food, funding usually goes to enforcement of apparel contracts, rather than food. This is true of the city of Los Angeles' Sweatfree Purchasing Ordinance.

The Good Food Purchasing Policy (GFPP), developed by the Los Angeles Food Policy Council, is groundbreaking because it equally embraces five overarching values (local, sustainable, fair, humane, and healthy) that together offer the food movement a holistic vision and framework for an equitable food system. Additionally, it focuses on supply chain transparency in an effort to document and verify progress toward reaching these values over time.

\section{The Development of the Good Food Purchasing Policy}

The Los Angeles Food Policy Council (LAFPC) was launched in 2010 based on the recommendation of then-Mayor Antonio Villaraigosa's Los 
Angeles Food Policy Task Force, which released a report called the Good Food for All Agenda (GFAA). Second author Delwiche was hired to staff the task force and then stayed on as the coordinator of the LAFPC. While the Office of the Mayor created the LAFPC, it is an independent nonprofit, largely funded by foundation grants. This independent structure with a close relationship to city leaders has proven important time and again when securing city, school district, or county support for LAFPC policy proposals.

Like other food policy councils across North America, the LAFPC was created with the recognition that a systems approach with deliberate crosssector collaboration and communication was desperately needed to heal our broken food system. While this initial concept brought local food movement leaders together, the success of the GFPP demonstrated that it was possible to make change through a comprehensive approach to systemic issues. The momentum generated by this victory helped to fuel several other cross-sector policy initiatives within the city of Los Angeles, such as street vending, food waste, and land access for urban food production policies.

The LAFPC working group that developed the GFPP included representatives from different sectors of the food movement, and included organizations such as the Food Chain Workers Alliance, Natural Resources Defense Council, Compassion Over Killing, and the Los Angeles County Department of Public Health, as well as farmers, processors, distributors, chefs, large public and private institutional buyers, school food advocates, and faith-based leaders. While working group members shared the common goal of leveraging the buying power of large institutions to bring good food to low-income communities in the greater Los Angeles area, they each brought their own interest to the table. The concept of good food, defined as food that is healthy, affordable, fair, and sustainable, has emerged over the last decade as a unifying framework for many within the food movement. The LA Food Policy Council's working group sought to develop a holistic, yet practical, operational, and uniform definition for large institutions and their vendors in their efforts to procure more good food.
First author Lo, with the Food Chain Workers Alliance, looked at the potential policy as a tool to improve wages and working conditions for workers in the food system. Small and midsized local farmers hoped the policy could help them sell their products to the school district and the city of Los Angeles, while representatives of local produce distributors such as the corporate executive chef and director of culinary \& business development for Coosemans LA Shipping supported farmers in this goal. A procurement specialist from the Los Angeles County Department of Public Health wanted more nutritious food to reach school children and seniors. Animal welfare organizations were interested in protecting the lives of animals. Environmental groups wanted a policy that would protect the environment and limit the use of antibiotics in meat production, among other goals.

None of these specific interests was necessarily in opposition to the others, and in the end each of the main participants in the working group strongly supported the proposed standards for other areas of concern in the policy. However, getting to this point was not always easy. At times during the process, there were heated exchanges among stakeholders. Tensions between support for fair labor practices on farms and support for small, local farmers rose to the surface, and the group struggled with the reality that few farms simultaneously support strong environmental sustainability, worker equity, and their own economic viability. With this recognition, the group decided to develop a tiered approach, with a requirement that a baseline standard be met in each of five value categories so that, for example, both labor rights and a preference for smaller and local farmers must reach a certain threshold. Few suppliers would meet criteria across all of the value categories, but together a variety of suppliers reflecting a range of principles and production practices, such as a large union farm or a small organic farm, would help an institution reach its goals of supporting a more equitable food system. The hope was, and still is, that more and more suppliers will be able to surpass the baseline in all five value categories as growing demand from public institutions pushes change in that direction.

The group deliberately structured the GFPP so 
that it addressed each issue area meaningfully, eliminating silos with no issue left behind in an effort to advance the others. At the same time, members understood that there were mutual benefits to each of the five values. Working group members who advocated for food workers' rights recognized that by supporting sustainability, they also made progress toward their goal of creating safer workplaces, and people who worked in public health identified the ways in which safe workplaces and fair wages can improve health outcomes for food system workers.

The diversity of the working group and the members' areas of focus helped to create what we believe to be the most comprehensive institutional food procurement policy in the country.

\section{The Good Food Purchasing Policy}

The GFPP supports five values: (1) local economies; (2) environmental sustainability; (3) valued workforce; (4) humane treatment of animals; and (5) health and nutrition (see Figure 1). The tiered, points-based scoring system allows participants to choose which level of commitment best suits the Good Food goals of their organization. Participants are then awarded one to five stars based on their total score.

Based on extensive research and a comparative analysis of procurement initiatives across the U.S., the GFPP is the only program of its kind in the country that requires a baseline standard to be met in each value category, so that institutions are not able to limit themselves to changes that are easy. Institutions must engage with difficult questions, such as how workers in their supply chain are treated or the public health, environmental, and animal welfare issues related to our current methods of livestock production to meet the global demand for meat. The goal of the GFPP is to give institutions an opportunity to have a transformative effect on the food system at every level.

For example, Institution A serves nutritious meals to low-income children. The institution would like to make purchases that support local businesses and well-paying jobs, so they have prioritized Local Economies, Valued Workforce, and Nutrition. They are satisfied meeting the baseline standard in Environmental Sustainability and Animal Welfare. The Center for Good Food Purchasing uses the scoring framework outlined in the Good Food Purchasing Standards to score an institution's purchasing data and assign points

\section{Figure 1. The Five Values of the Good Food Purchasing Policy}

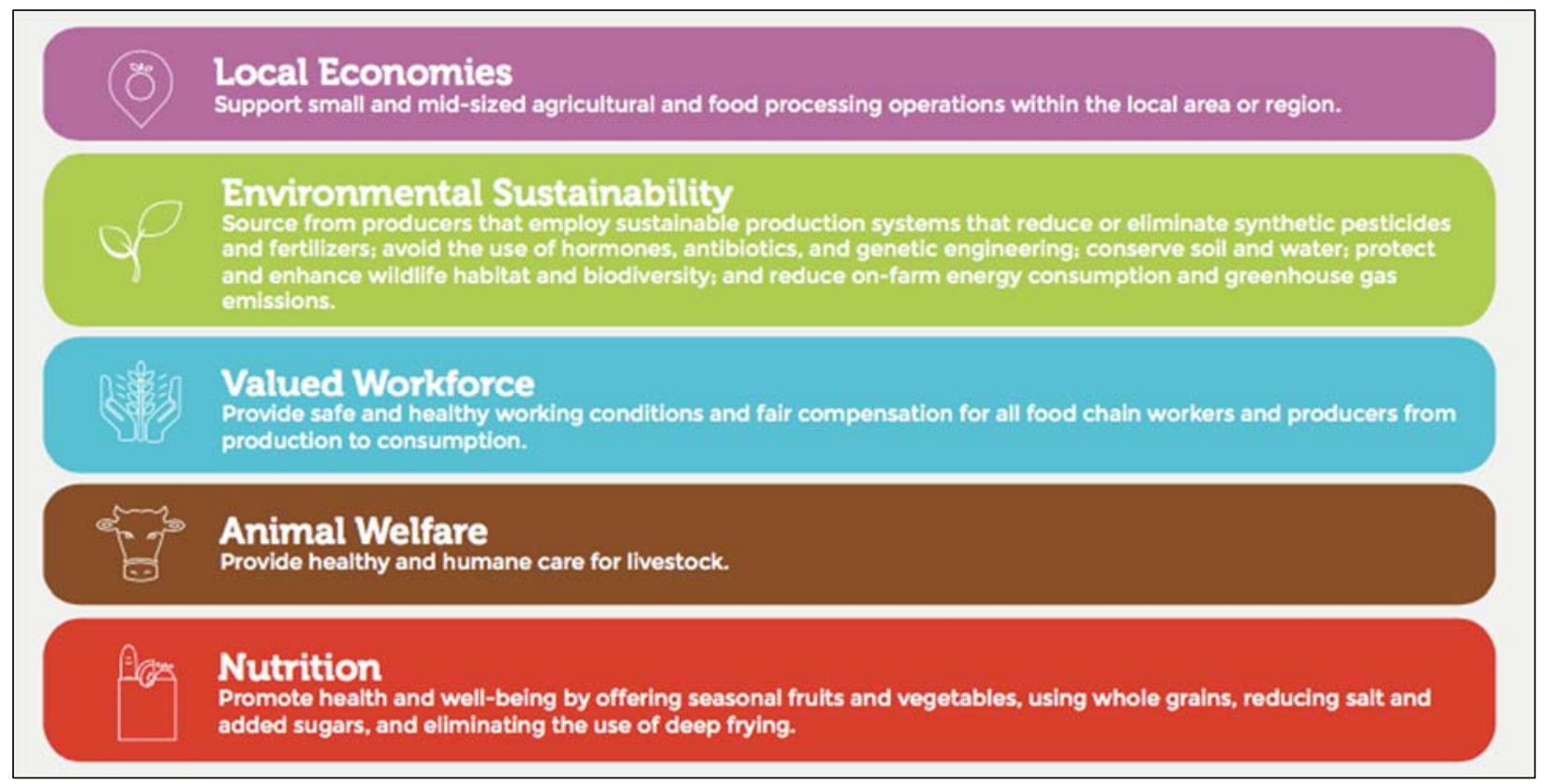

Image courtesy of the Center for Good Food Purchasing. 
within each of the five value categories based on its overall performance. Each of the five value categories has a baseline standard. To become a Good Food Provider, an institution must meet at least the baseline (equal to one point) in each of the five values; however, within each category there are three levels and more points are awarded for achievement at higher levels in each category, allowing institutions to earn more points in their high priority categories. Standards are based on third-party certifications and label claims that have been identified as meaningful and ranked by national experts in each category. Points earned in each category are added together to determine overall number of points earned. A star rating is awarded. Figure 2 shows how the scoring system works.

In the Valued Workforce category, the baseline standard is compliance with employment law and the core values of the International Labour Organization (Clean Clothes Campaign):

1. Freedom of association and the right to collective bargaining.

2. Elimination of all forms of forced or compulsory labor.

3. Abolition of child labor.

4. Elimination of discrimination with respect to employment or occupation; and

If a supplier is found to have serious health and safety and/or wage and hour violations within the past five years, Institution A must request information from that supplier about steps taken to mitigate past violations and prevent future violations.

To receive more points in the Valued Workforce category,
Institution A must meet the baseline standard and source at least 5 percent of its annual food spend from a supplier that meets the higher standards in Level 2 or Level 3. The institution is expected to increase this percentage to at least 15 percent within five years.

A farm or food business can qualify at Level 2 if the organization:

- Has a social responsibility policy, which includes: (1) union or nonpoverty wages; (2) respect for freedom of association and collective bargaining; (3) safe and healthy working conditions; and (4) prohibition of
Figure 2. GFPP Scoring Example

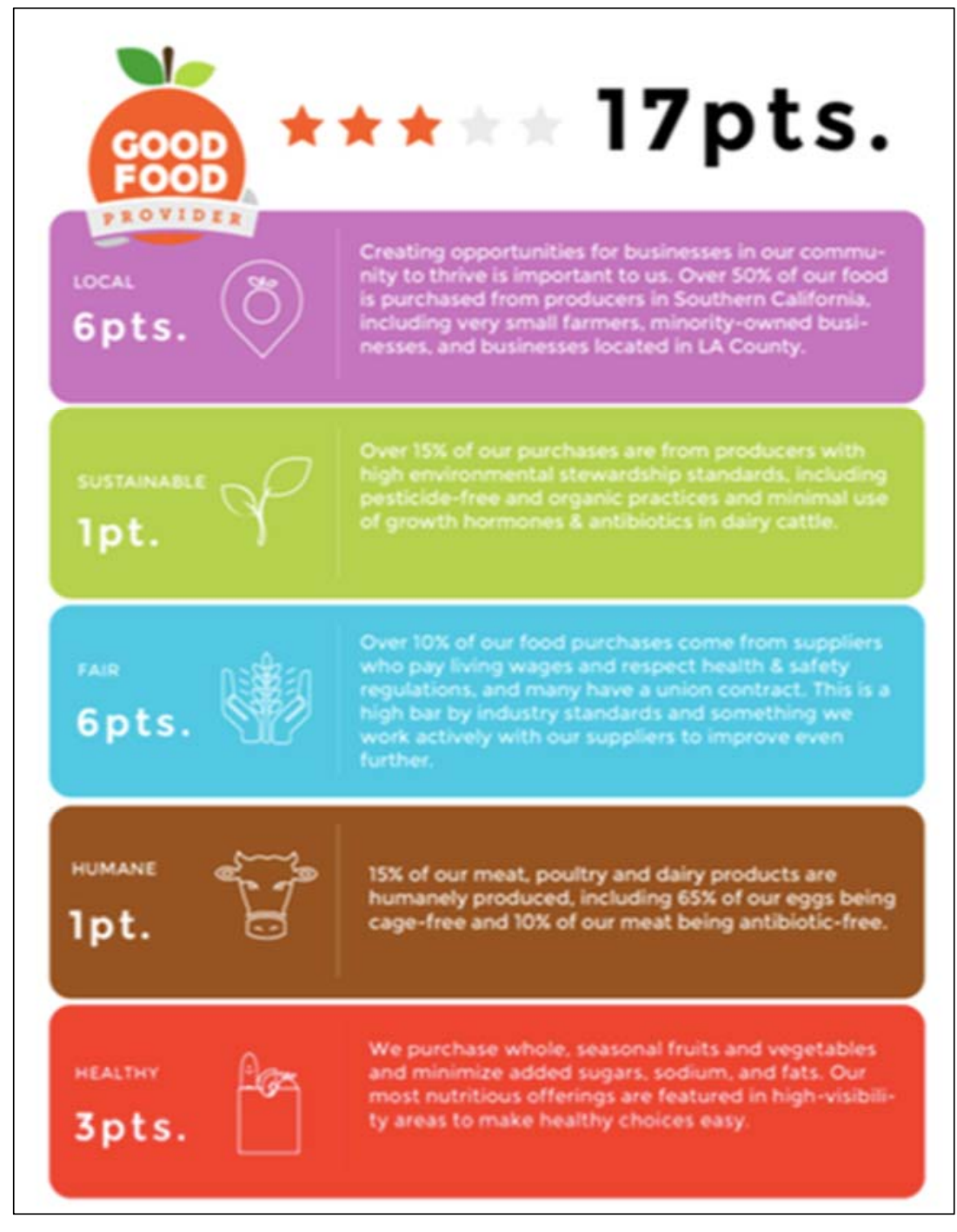

Image courtesy of the Center for Good Food Purchasing. 
child labor, except as allowed by domestic law; and at least one additional employment benefit, such as (5) health care benefits; (6) paid sick days; (7) profit-sharing with all employees; or

- Is Fair Trade Certified (for international products); or

- Has Fair for Life certification

To meet Level 3, a farm or food business must:

- Have a union contract with its employees; or

- Be a worker-owned cooperative; or

- Have signed the Coalition of Immokalee Workers' Fair Food Supplier Code of Conduct; or

- Be "Food Justice-Certified" by the Agricultural Justice Project; or

- Be certified by the Equitable Food Initiative.

The baseline standard matched existing sweatfree procurement policies within the city of Los Angeles and the Los Angeles Unified School District. As discussed above, no resources were approved by the city council and the mayor to enforce the policy in these institutions' food supply chains. The GFPP fills this void by providing a mechanism for verification and enforcement through the Center for Good Food Purchasing.

The modest 5\% target at Levels 2 and 3 was established with the recognition that the existing supply of "fair" food, as defined by the Good Food Purchasing Standards, would be relatively low and it would take time to build the market for it. It was also acknowledged that there is a perception that "fair" food is prohibitively expensive. GFPP implementation has helped to debunk this myth in two ways. First, worker wages account for such a small share of the final price consumers pay for food that slightly higher wages for food chain

\footnotetext{
${ }^{1}$ The LA Food Policy Council developed and incubated the Good Food Purchasing Program, following the city and LA Unified School District's adoption of the GFPP. As of July 2015, the Center for Good Food Purchasing (CGFP), a
}

workers translates to only a modest increase to the end price for consumers (Benner \& Jayaraman, 2012). If we use union-produced food as a proxy for higher wages for workers, we find little to no cost differential between union and non-union food products. In fact, based on the Center for Good Food Purchasing's baseline analysis of food purchases by the city of Los Angeles and LAUSD in 2013, many institutions were unknowingly already buying these products (Los Angeles Food Policy Council, 2013), which leads to a second point: most union-made food products come from large-scale operations, which also benefit from economies of scale, resulting in lower prices for consumers. While many of these companies' environmental sustainability practices may be questionable, they are often industry leaders in terms of employee wages, benefits, and rights. The GFPP recognizes and works with the inherent trade-offs and paradoxes within our current food system.

Another hallmark of the GFPP is its requirement for supply chain transparency and third-party verification, which in our opinion is the first step for creating change in the food industry. Under the policy, institutions submit semiannual reports on all food purchasing records for minimally processed, single-ingredient items to the Center for Good Food Purchasing (CGFP). ${ }^{1}$ The CGFP administers the Good Food Purchasing Program to verify compliance, provide technical assistance, and celebrate success. This reporting process requires vendors and distributors to trace a product back to the producer and provide the name of the farm, processing facility, and wholesaler. CGFP staff then research each supplier to determine where it fits in each value category. This research provides the basis for scoring how much Good Food an institution is purchasing and, therefore, how many stars it can receive. Included in the GFPP is an expectation for the institution to publicly report its progress in implementing the policy each year. The CGFP provides each institution with an annual

national nonprofit created to guide the national expansion of GFPP, began managing the Good Food Purchasing Program for LA-institutions, as well as all other U.S. institutions that adopt the GFPP. 
score and progress report, which provides the basis for the institution's public report.

\section{The Impact and Vision of the \\ Good Food Purchasing Policy}

Mayor Antonio Villaraigosa issued an executive order on October 24, 2012, requiring city departments with food budgets of US $\$ 10,000$ or more to implement the GFPP at the baseline level or higher. The city council of Los Angeles adopted a motion reaffirming this commitment and directing the chief administrative officer to report on implementation progress annually. A few weeks later, in November 2012, the board of the Los Angeles Unified School District (LAUSD) also adopted the GFPP.

The GFPP affects 750,000 meals served daily by LAUSD and the city of Los Angeles. In the years following adoption of the policy, we have seen positive results, largely due to its role in helping to shift the food purchasing decisions of LAUSD, the second largest food purchaser in California, with an annual food budget nearing US $\$ 150$ million. The GFPP's supply chain transparency requirement, focus on metrics, and outside verification by CGFP staff provide LAUSD with the opportunity to measure its progress over time.

LAUSD's participation in the GFPP has led to the redirection of at least US $\$ 10$ million for produce purchasing from local growers. In just two years, the district doubled the amount of its food budget spent locally to about $50 \%$, which led to the creation of at least 200 new, well-paying food chain jobs in LA County. Jobs were created on farms, in fruit and vegetable processing, and in bread manufacturing and distribution (Watanabe, 2013; PolicyLink, 2015). The district also reduced its meat purchases by nearly $15 \%$ following the adoption of Meatless Monday and made a commitment to sourcing $100 \%$ antibiotic-free chicken by December 2016.

LAUSD's participation in the GFPP is having ripple effects on the business practices of other supply chain partners. LAUSD's produce and bread distributor, a company that provides produce and other food items for over three million school meals per day across the western U.S., has transformed its internal tracking systems of suppliers, and suppliers that do not meet GFPP standards must commit to doing so or "are shown the door" (Leer, 2015). This distributor also brokered a relationship to work with sustainable wheat farmers in California to become the primary source of grain for baking products for the school district and for 115 other school districts for which the company provides food.

But what impact, if any, has the GFPP had on improving conditions for food chain workers? What may seem like small steps on the surface are actually unprecedented actions taken by institutions in monitoring working conditions along the food chain. Through a rigorous verification process, which includes an in-depth assessment of each supplier's production practices, such as size of operation, geographic location, label claims, thirdparty certifications related to any of the value categories, union contracts, and any federal, state, or local labor violations over the last five years, CGFP staff assess how supplier practices stack up against GFPP standards. This detailed assessment identifies food producers who have strong and poor records on safe and fair labor practices, which were never previously tracked either at the participating Los Angeles-based institutions or elsewhere. This knowledge has enabled administrators and elected officials to recognize problematic suppliers and start thinking about options for improving their supply chains. It has also revealed suppliers that offer their workers wages and benefits far above the industry standard, from whom institutions begin sourcing more.

In the case of LAUSD and per compliance with the baseline standard in the Valued Workforce category of GFPP, the district sent letters to vendors and suppliers with serious labor violations over the past five years, asking what steps were taken to address the documented violations and prevent future violations. These letters indicate to vendors and suppliers that the district is maintaining vigilance over its supply chain in terms of workers' rights. In the spring of 2015, citing the GFPP, the school board approved a United Farm Worker (UFW)-sponsored resolution, calling on Gerawan, a major California grower, to honor its union contract with the UFW. GFPP also contributed to higher wages and improved working 
conditions for over 160 truck drivers in LAUSD's supply chain who recently joined the International Brotherhood of Teamsters union and negotiated a first contract in August 2015.

Most recently, the power of GFPP as a coalition-building tool and public accountability mechanism has been put to the test. At the end of August 2015, a multistakeholder coalition of local, state, and national organizations, organized and led by the Food Chain Workers Alliance (FCWA), successfully fought against LAUSD administration's decision to award new five-year chicken contracts to Tyson and Pilgrim's Pride, the two largest chicken processing corporations in the U.S. Part of the argument for recommending these contract awards, despite the companies' noncompliance with multiple value categories of the GFPP, was that these companies offered the best price for the district. Within five days of the public announcement of this decision, over 20 organizations sent letters to the school board members, and the FCWA also organized a call-in day for August 30, the day before the LAUSD board was set to vote on the chicken contracts. As a result of these letters as well as questions that LAUSD board members were raising internally in response, the administration withdrew its recommendation to the school board. At the end of October, the LAUSD issued a new request for proposals (RFP) for its chicken contracts to allow distribution companies to bid. This was one of the coalition's demands, since distribution companies were not permitted under the previous RFP and since three union distributors serve school districts in Southern California. The LAUSD board of directors was scheduled to vote on the new chicken contracts on March 8, 2016.

\section{Potential National Impact}

The GFPP and the supply chain transparency it requires have achieved two significant goals in Los Angeles that can serve as a model for the rest of the country. First, the GFPP has helped institutions make more informed decisions about the suppliers they would like to work with-those who represent and uphold their values. Second, the GFPP is increasing public accountability of elected officials by mobilizing constituents to demand that the use of millions of dollars in taxpayer-funded food contracts approved each year reflect community values related to supporting local economies, environmental sustainability, fair labor practices, animal welfare, and nutrition for all, as well as provide the highest quality food to communities who need it most.

The GFPP is a model that can be adapted around the country. To this end, the LAFPC spun off the Good Food Purchasing Program in July 2015 to become its own entity, the Center for Good Food Purchasing (CGFP), to coordinate the national expansion. A coalition of national organizations, including the FCWA, PolicyLink, the Health, Environment, Agriculture, and Labor (HEAL) Food Alliance, and the International Brotherhood of Teamsters are working with food policy councils and local grassroots coalition to win adoption and implementation of the GFPP in cities and school districts around the country. Once the GFPP is adopted, the CGFP manages the policy to verify compliance, assist participating foodpurchasing institutions in fulfilling their goals and commitments, and monitor and reward progress over time. So far, the GFPP has been funded by foundation grants. As the program expands and the need to become a self-sustaining model grows, institutions may be asked to pay a small fee to participate in the program, not unlike the Leadership in Energy and Environmental Design (LEED) Green Building Certification model.

Organizing to win adoption of the GFPP in the city and the school district of Chicago has already begun. In February 2015, the FCWA, in partnership with the Chicago Food Policy Action Council (CFPAC), began asking local organizations in Chicago to sign on to a letter to Mayor Rahm Emanuel and the opposing mayoral candidate Chuy Garcia to publicly endorse GFPP. Both did. Those 25 organizations and others that the FCWA and the CFPAC have since recruited are creating a multisector coalition to ensure that Emanuel, who was re-elected in March 2015, follows through on his endorsement. Upon the request of the mayor's office, the FCWA and CFPAC, with technical assistance and verification provided by the CGFP, are working with the Chicago Park District to conduct a pilot program implementing the GFPP, 
even before the city has officially adopted the policy. Organizations in additional cities across the country are in various stages of building coalitions and advancing the GFPP.

\section{Conclusion}

If efforts to create a shared collective agenda prove successful, a unified food movement holds tremendous potential for healing our food system. The Good Food Purchasing Policy offers one such model.

We believe that purchasing food based on the GFPP framework is a pathway for building sustainable and socially just regional food systems that revitalize local economies so that all residents can prosper. We have already witnessed that "Good Food" purchasing provides access to healthy food for low-income families and communities of color, which can help address issues of hunger and obesity. As shown in Los Angeles on a small scale to date, "Good Food" purchasing has the potential to create hundreds of good, high-quality jobs throughout the food chain, from production and processing to distribution and food service. Livingwage jobs result in significant long-term benefits to workers, including increased wealth, quality of life, and purchasing power for food, shelter, and health care. Our vision for the GFPP is that the policy will shift farmers and other producers to use more sustainable production practices that not only conserve natural resources, but also reduce farmworker and consumer exposure to harmful chemicals, and support a safe drinking water supply for agricultural communities. Reduced reliance on antibiotics for animal production, another standard in the GFPP, should result in more humane conditions for livestock while minimizing the spread of antibiotic-resistant bacteria to humans through meat consumption. Future research on the cost differentials between conventional food products and food products embodying a range of "Good Food" attributes in participating institutional supply chains will help build the case for broader adoption and implementation of the GFPP. Additionally, we would like to use the data we collect from institutions to calculate in the aggregate the economic, environmental, health, and social impacts related to these purchasing shifts in order to document in concrete terms why procurement matters.

While the GFPP leverages institutional buying power to effect food system change, more importantly, the policy establishes an opportunity for multisector coalitions to work together around a shared vision for change. Using a replicable model focused on ensuring that public food contracts reflect the values of their constituents, the GFPP serves as a tool to help unify diverse sectors of the food movement both locally and nationally. In doing so, the GFPP can help grow a food movement that has been gaining traction over the last decade. The campaign to win adoption and implementation of the policy can set the stage for more collaboration among organizations and individuals from diverse sectors.

\section{References}

Barlett, P. F. (2011). Campus sustainable food projects: Critique and engagement. American Anthropologist, 113(1), 101-115. http://dx.doi.org/10.1111/j.15481433.2010.01309.x

Benner, C., \& Jayaraman, S. (2012, October 24). A dime a day: The impact of the Miller/Harkin minimum wage proposal on the price of food. Food Labor Research Center at the University of California, Berkeley. Retrieved from http://laborcenter.berkeley.edu/ pdf/2012/price food12.pdf

Bittman, M. (2015, September 12). A farewell. The New York Times. http://www.nytimes.com/2015/09/ 13/opinion/sunday/mark-bittman-a-farewell. html? $\mathrm{r}=0$

Clean Clothes Campaign. What are ILO conventions and core labor standards? Retrieved from http://www.cleanclothes.org/issues/faq/ilo de Schutter, O. (2014). The power of public procurement: Public purchasing in the service of realizing the right to food. Official Report to the UN Human Rights Council. Retrieved from http://www.srfood.org/images/ stories/pdf/otherdocuments/20140514 procurement_en.pdf

Delwiche, A., \& Lo, J. (2013). Los Angeles’ Good Food Purchasing Policy worker, farmer and nutrition advocates meet...and agree! Progressive Planning, 197, 24-28. 
Friedmann, H. (2007). Scaling up: Bringing public institutions and food service corporations into the project for a local, sustainable food system in Ontario. Agriculture and Human Values, 24(3), 389398. http://dx.doi.org/10.1007/s10460-006-9040-2

Holt-Giménez, E., \& Wang, Y. (2011). Reform or transformation? The pivotal role of food justice in the U.S. food movement. Race/Etbnicity, 5(1), 83102.

Leer, S. (2015, September 16). Healthy, Hunger-Free Kids Act changed the way schools do food. Daily Bulletin. Retrieved from http://www.dailybulletin. com/opinion/20150916/healthy-hunger-free-kidsact-changed-the-way-schools-do-food-guestcommentary

Los Angeles Food Policy Council. (2013). Los Angeles food system snapshot 2013. Los Angeles: Author. Retrieved from http://goodfoodla.org/goodfood/2013-food-system-snapshot/

Myers, J. S., \& Sbicca, J. (2015). Bridging good food and good jobs: From secession to confrontation within alternative food movement politics. Geoforum, 61, $17-26$.

http://dx.doi.org/10.1016/i.geoforum.2015.02.003
PolicyLink. (2015). The Los Angeles Good Food Purchasing Program: Changing local food systems, one school, supplier, and farmer at a time.

Retrieved from http://www.policylink.org/sites/ default/files/LA GFFP FINAL 0.pdf

Pollan, M. (2010, May 20). The food movement, rising [Republished from The New York Review of Books]. Retrieved from http://michaelpollan.com/articlesarchive/the-food-movement-rising/

Pollan, M. (2011, September 14). How change is going to come to the food movement. The Nation.

Retrieved from http://www.thenation.com/article/ how-change-going-come-food-system/

Sbicca, J. (2015). Food labor, economic inequality, and the imperfect politics of process in the alternative food movement. Agriculture and Human Values, 32(4), 675-687. http://dx.doi.org/10.1007/s10460015-9582-2

Watanabe, T. (2013, November 24). L.A. Unified's local food push is healthy for area economy too. Los Angeles Times. Retrieved from http://articles.latimes.com/2013/nov/24/local/la$\underline{\text { me-lausd-food-20131124 }}$ 